\title{
Transposition of a Gene Encoding OXA-2 $\boldsymbol{\beta}$-Lactamase
}

\author{
By J. KRATZ, F. SCHMIDT AND B. WIEDEMANN* \\ Institut für Medizinische Mikrobiologie und Immunologie der Universität Bonn, \\ An der Immenburg 4, 5300 Bonn 1, Federal Republic of Germany
}

(Received 20 January 1983; revised 15 April 1983)

\begin{abstract}
A bla gene encoding OXA-2 $\beta$-lactamase has been transposed from the Salmonella typhimurium $R$ plasmid R1767. This transposable element which was designated Tn2410 encoded sulphonamide and mercury resistance in addition to the bla gene. It had a size of $18.5 \mathrm{~kb}$ and appeared to be flanked by small inverted repeats. Restriction enzyme analysis resulted in a detailed map of $\operatorname{Tn} 2410$, which showed a high degree of similarity with the published map of Tn2603, a transposon encoding OXA-1 $\beta$-lactamase. The ampicillin and sulphonamide resistance genes on $\operatorname{Tn} 2410$ were mapped in a cluster on the region between the centre and the right end of the map.
\end{abstract}

\section{INTRODUCTION}

Plasmid mediated resistance to penicillins and cephalosporins is due mainly to the formation of $\beta$-lactamases. Eleven types of plasmid specified $\beta$-lactamases have been identified (Matthew, 1979 ). They differ in their ability to hydrolyse $\beta$-lactam antibiotics, in their isoelectric points, immunological properties, susceptibility to inhibition and molecular weights (Dale \& Smith, 1974; Matthew \& Harris, 1976; Matthew et al., 1979).

The TEM-type enzyme is the most frequently found bacterial $\beta$-lactamase (Matthew, 1979). Other lactamases like the OXA-type enzyme are less common but have been reported in Escherichia coli, Enterobacter cloacae, Klebsiella pneumoniae, and Salmonella typhimurium (Simpson et al., 1980; Sykes \& Matthew, 1976). The OXA-enzymes hydrolyse the semi-synthetic oxacillin, that is resistant to hydrolysis by the TEM-type enzyme (Dale \& Smith, 1974). There are three different groups of $\beta$-lactamases that hydrolyse oxacillin: OXA-1, OXA-2, and OXA-3. These enzymes are distinct from one another in molecular weights and isoelectric points (Dale \& Smith, 1974; Matthew et al., 1979).

TEM-1 and 2 are often carried by transposons such as Tn1, Tn2 and Tn3 (Benedick et al., 1977; Hedges \& Jacob, 1974; Heffron et al., 1975; Kopecko \& Cohen, 1975; Yamada et al., 1979). Transposition is thought to play an important role in the rapid epidemiological spread of resistance genes (Kopecko, 1980), but there has been only one report of a transposon encoding an OXA $\beta$-lactamase (Yamamoto et al., 1981). That transposon (Tn2603) carries genes for OXA-1 enzyme, and for resistance to streptomycin, sulphonamides and mercury. In this paper we describe a transposon ( $\operatorname{Tn} 2410)$ derived from plasmid R1767 originally isolated from $S$. typhimurium (Schmidt et al., 1982). It is $18.5 \mathrm{~kb}$ in size, mediates resistance to ampicillin (by OXA-2 enzyme), sulphonamides, and mercury. This paper reports the physical and genetical map of $\operatorname{Tn} 2410$.

\section{METHODS}

Bacterial strains and plasmids. The bacterial strains and plasmids used in this study are listed in Table 1. Plasmid R 1767 was originally isolated from a clinical strain of Salmonella typhimurium and codes for resistance to chloramphenicol, tetracycline, ampicillin, sulphonamides, streptomycin, spectinomycin, mercury, and Coll production (Schmidt et al., 1982). 


\section{Table 1. Bacterial strains and plasmids}

Nomenclature is according to the recommendations of Demerec et al. (1966) and Novick et al. (1976).

Strain* Relevant characteristics

E. coli WA $921 \mathrm{Nal}^{\mathrm{r}}$

E. coli SK 1592

E. coli JC 2926 Rif $^{r}$

Proteus mirabilis PM13

Plasmid

R1767

pUB307

pBR322

pPB 12

pBP401

pBP402

pPB403 lac thr leu met thi hsd

gal thi $\mathrm{T} 1^{\mathrm{r}}$ sbc B15 hsr4 hsm

recA thi thr arg his leu mal

$\mathrm{Ap}^{\mathrm{r}} \mathrm{Su}^{\mathrm{r}} \mathrm{Tc}^{r} \mathrm{Cm}^{\mathrm{r}} \mathrm{Sm}^{\mathrm{r}} \mathrm{Sp}^{\mathrm{r}} \mathrm{Hg}^{\mathrm{r}}$ Coll $\mathrm{Tra}^{+}$

$\mathrm{Km}^{r} \mathrm{Tc}^{\mathrm{r}} \mathrm{Tra}^{+}$

$\mathrm{Ap}^{\mathrm{r}} \mathrm{Tc}^{\mathrm{r}}$

$\mathrm{Ap}^{\mathrm{r}} \mathrm{Su}^{\mathrm{r}}$

$\mathrm{Ap}^{\mathrm{r}} \mathrm{Tc}^{\mathrm{r}} \mathrm{Su}^{\mathrm{r}} \mathrm{Hg}^{\mathrm{r}}$
Source or reference

Wood (1966)

Kushner (1978)

Bachmann (1972)

Coetzee (1963)

Schmidt et al. (1982)

Bennett et al. (1977)

Bolivar et al. (1977)

This paper

This paper: pBR322:: $\operatorname{Tn} 2410$

* The $E$. coli strains derived from $E$. coli $\mathrm{K} 12$.

Media and drugs. L broth (LB) and agar (LA) (Lennox, 1955) were used for the growth of bacterial strains; IsoSensitest agar (Oxoid) for the determination of sulphonamide resistance. Antibiotics were added at the following concentrations: sulphonamide $300 \mu \mathrm{g} \mathrm{ml}^{-1}$; kanamycin $50 \mu \mathrm{g} \mathrm{ml}^{-1}$; ampicillin $15 \mu \mathrm{g} \mathrm{ml}^{-1}$; tetracycline $10 \mu \mathrm{g} \mathrm{ml}^{-1}$; nalidixic acid $100 \mu \mathrm{g} \mathrm{ml}^{-1}$; rifampicin $50 \mu \mathrm{g} \mathrm{ml}^{-1}$; streptomycin $10 \mu \mathrm{g} \mathrm{ml}^{-1}$; chloramphenicol $25 \mu \mathrm{g} \mathrm{ml}^{-1}$, and $\mathrm{HgCl}_{2} 20 \mu \mathrm{g} \mathrm{ml}^{-1}$.

Identification of $\beta$-lactamases. Analytical isoelectric focusing of crude cell extracts on polyacrylamide gels (LKB) was used for characterization of plasmid-mediated $\beta$-lactamases (Matthew et al., 1975), with $\beta$-lactamases TEM1, TEM-2, OXA-1, OXA-2, and OXA-3 as references.

Isolation of plasmid DNA. Isolates from $5 \mathrm{ml}$ cultures were screened for plasmid content by the procedure of Klein et al. (1980). Plasmid DNA from $500 \mathrm{ml}$ cultures were prepared according to the Triton X-100 cleared lysate technique described by Kuperszock-Portnoy et al. (1974), and centrifuged in ethidium bromide-CsCl gradients.

Genetic transfer. Conjugation was carried out on membrane filters. For this procedure $1 \mathrm{ml}$ donor cells and $4 \mathrm{ml}$ recipient cells of exponentially growing cultures were mixed and filtered through membrane filters (pore size $0.45 \mu \mathrm{m})$. The filters were placed on LA plates for $2 \mathrm{~h}$ at $37^{\circ} \mathrm{C}$, then the cells were washed from the filters with LB, diluted and plated on selection plates. Escherichia coli strain SK1592 was transformed with plasmid DNA as described by Kushner (1978).

Electron microscopy. Heteroduplex molecules were prepared by the formamide technique of David et al. (1971). For calculations of length, double and single stranded DNA's of phage $\phi \times 174$ were used as internal standards (5357 bp) (Sanger et al., 1977). Contour lengths were measured with a Numonics digitizer.

Restriction enzyme analysis. Digestion of plasmid DNA and agarose gel electrophoresis in a horizontal gel apparatus (BRL, Neu-Isenburg, F.R.G.) was performed as described by Schmidt et al. (1982).

\section{RESULTS}

\section{Transposition of OXA-2 gene on to plasmid pUB307}

Plasmid R1767, originally isolated from Salmonella typhimurium (Schmidt et al., 1982) is not transmissible to Proteus mirabilis PM13. This enabled us to demonstrate the transposition of an OXA-2 resistance gene from R1767 to plasmid pUB307, which transfers efficiently to $P$. mirabilis PM13. Escherichia coli recA strain JC2926 carrying R 1767 and pUB307 was mated with $P$. mirabilis PM13. Fifty ampicillin resistant $P$. mirabilis transconjugants were used as donors to $E$. coli WA921. All $E$. coli transconjugants selected on ampicillin showed the resistance pattern of pUB307 $\left(\mathrm{Km}^{\mathrm{r}}, \mathrm{Tc}^{\mathrm{r}}\right)$ and in addition, the markers $\mathrm{Ap}^{\mathrm{r}}, \mathrm{Su}^{\mathrm{r}}, \mathrm{Hg}^{\mathrm{r}}$, but not $\mathrm{Cm}^{\mathrm{r}}$ or $\mathrm{Sm}^{\mathrm{r}}$, hence the plasmid carried at least part of R1767. In further conjugation experiments with two of these clones, all resistance markers cotransferred irrespective of which one was used for selection. This is consistent with the transposition of a genetic element of R1767 carrying resistance genes for ampicillin, sulphonamides and mercury to plasmid pUB307. The presumptive transposon was designated Tn2410. 
Table 2. Sizes of HindII fragments $(k b)$ of hybrid plasmids pBP401, pBP402 and pBP403 (pBP322::Tn2410)

\begin{tabular}{cccc} 
pBP401 & $\mathrm{pBP402}$ & $\mathrm{pBP403}$ & $\mathrm{pBP322}$ \\
& 3.61 & & \\
3.46 & 3.46 & 3.46 & \\
3.38 & & & 3.26 \\
& & 3.23 & \\
3.15 & 3.15 & 3.15 & \\
3.00 & 3.00 & 3.00 & \\
2.54 & 2.54 & 2.54 & \\
2.23 & 2.23 & 2.23 & \\
1.85 & 1.85 & 1.85 & \\
1.35 & & 1.5 & \\
1.10 & 1.15 & & \\
\hline 0.52 & $\underline{1.10}$ & $\underline{1.10}$ & \\
0.25 & 0.52 & 0.52 & \\
& 0.25 & 0.25 &
\end{tabular}

\section{Identification of the $\beta$-lactamases}

From two clones of $E$. coli WA921 (pUB307::Tn2410) a crude enzyme preparation was prepared and the isoelectric point of the $\beta$-lactamase was determined by isoelectric focusing. For comparison, crude lysates of several strains producing known $\beta$-lactamases were isofocused simultaneously. The bands of the $\beta$-lactamase produced by WA921 (pUB307:: Tn2410) were at a pH of 7.7 and 7.45 and were identical with the bands of crude extracts from an E. coli strain containing R1818, a plasmid coding for OXA-2 enzyme (Matthew et al., 1979).

\section{Transposition of Tn2410 on to $p B R 322$}

Plasmid DNA from the E. coli recA strain JC2926 harbouring pBR322 and pUB307 : : Tn 2410 was prepared by the method of Klein et al. (1980) and used to transform E. coli SK1592. A high concentration of ampicillin $\left(2 \mathrm{mg} \mathrm{ml}^{-1}\right)$ was used to select for the multicopy plasmid pBR322 that encodes TEM-1 $\beta$-lactamase. Strains harbouring plasmids coding only for OXA-2 enzyme are unable to grow under these conditions, as the TEM-type enzyme is about 11 times more efficient than the OXA-type enzyme (Hedges et al., 1974). Sulphonamide was used to select for Tn2410. Transformants were checked for sensitivity to kanamycin to discriminate hybrid plasmids from cells containing both parent plasmids. Twenty-four of 200 clones tested were $\mathrm{Ap}^{\mathrm{r}}$, $\mathrm{Tc}^{\mathrm{r}}, \mathrm{Su}^{\mathrm{r}}, \mathrm{Hg}^{\mathrm{r}}$, but $\mathrm{Km}^{\mathrm{s}}$. In agarose gel electrophoresis, DNA from these clones showed only one band with a size of $23 \mathrm{~kb}$ and no bands corresponding to pBR322 or to pUB307::Tn2410. Purified DNA's of three plasmids, pBP401, pBP402, and pBP403, together with pBR322 DNA were digested with $H$ indII endonuclease and fragment sizes were determined by agarose gel electrophoresis (Table 2). The $1.1 \mathrm{~kb}$ pBR322 HindII fragment was present in all three replicons. Eight of the remaining 10 fragments were common to all three plasmids; the two fragments that were different, indicated that the transposon inserted in three different sites in the $3.26 \mathrm{~kb}$ HindII fragment of pBR322.

\section{Construction of a restriction endonuclease cleavage map of Tn2410}

DNA of one of the recombinant plasmids, pBP403, was completely digested with the restriction endonucleases EcoRI, BamHI, HindIII, HindII, SalI, BglII, PstI, or SmaI and the resulting DNA digests were electrophoresed on agarose gels of $0.7 \%(w / v)$ to $1.2 \%(w / v)$ depending on the size of fragments separated. The sizes and number of the resulting fragments are shown in Table 3. The relative locations of restriction enzyme cleavage sites on pBP403 were determined mainly by a series of double digestion experiments and by comparison of the cleavage patterns with that of pBR322 (Sutcliffe, 1978). Fragments smaller than about $0.2 \mathrm{~kb}$ 
Table 3. DNA fragments generated by digestion of pBP403 ( $p B R 322:: T n 2410) D N A$ with restriction enzymes

Sizes of fragments $(\mathrm{kb})$ generated by:

\begin{tabular}{|c|c|c|c|c|c|c|c|c|}
\hline & HindII & EcoRI & $H$ indIII & BamHI & Pst $\mathrm{I}$ & SalI & SmaI & $B g l$ II \\
\hline $\mathbf{A}$ & 3.46 & $4 \cdot 70$ & $10 \cdot 30$ & $11 \cdot 20$ & $13 \cdot 4$ & $11 \cdot 7$ & $22 \cdot 5$ & $22 \cdot 5$ \\
\hline B & 3.23 & 4.45 & $5 \cdot 61$ & $7 \cdot 10$ & $9 \cdot 2$ & 11.0 & & \\
\hline $\mathrm{C}$ & $3 \cdot 15$ & $4 \cdot 15$ & 3.61 & $4 \cdot 10$ & & & & \\
\hline D & 3.00 & 3.54 & 2.90 & $0 \cdot 22$ & & & & \\
\hline $\mathbf{E}$ & $2 \cdot 54$ & $2 \cdot 15$ & $0 \cdot 30$ & & & & & \\
\hline $\mathbf{F}$ & $2 \cdot 23$ & $2 \cdot 08$ & $0 \cdot 18$ & & & & & \\
\hline G & 1.85 & $1 \cdot 23$ & & & & & & \\
\hline $\mathrm{H}$ & $1 \cdot 50$ & 0.25 & & & & & & \\
\hline I & $1 \cdot 10$ & 0.22 & & & & & & \\
\hline $\mathbf{J}$ & 0.52 & & & & & & & \\
\hline $\mathrm{K}$ & $0 \cdot 25$ & & & & & & & \\
\hline
\end{tabular}

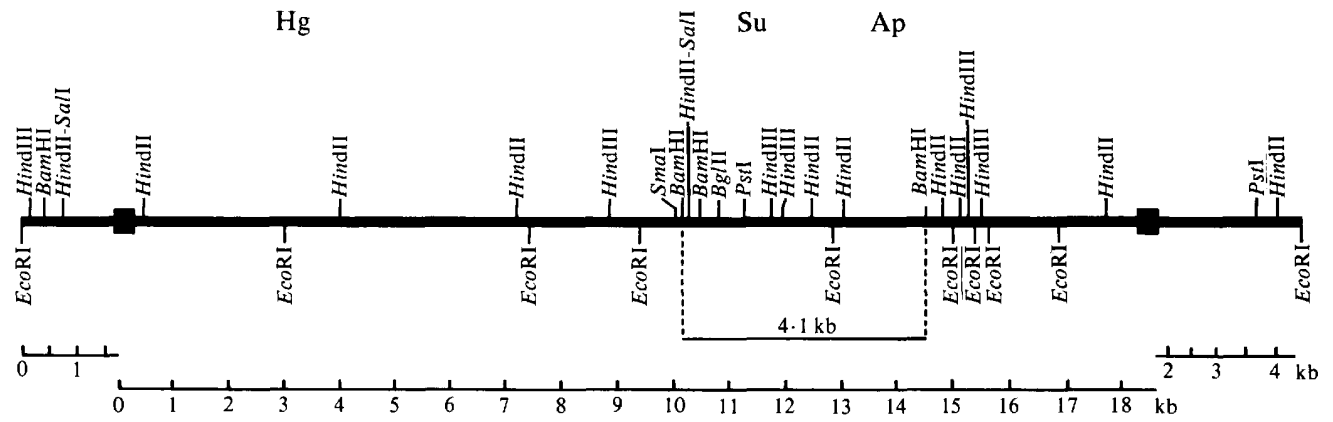

Fig. 1. Physical and functional map of pBR322: :Tn2410. Black boxes indicate the inverted repeats, flanking the transposable element. Coordinates are given in kilobases relative to the single EcoRI site in the vector plasmid pBR322. The positions of resistance genes on Tn2410 are indicated. The bar indicates the $4 \cdot 1 \mathrm{~kb}$ BamHI fragment which carries the Ap Su genes and is homologous to pBP12.

would not have been detected in the gels used. The final map generated by these studies is presented in Fig. 1.

Heteroduplexes between PstI-cleaved molecules of pBR322 and pBP403 showed that the transposable element was flanked by short inverted repeats. Comparative measurements of the inverted repeat flanking $\operatorname{Tn} 2410$ and $\operatorname{Tn} 3$ [38 nucleotides (Ohtsubo et al., 1979)] revealed the same order of magnitude for both sequences (data not shown).

The integration site of Tn 2410 in pBR322 in the recombinant plasmid pBP403 determined by restriction analysis and measurements of heteroduplex structures was localized on the restriction map of pBR322 at position $1.75 \mathrm{~kb}$ clockwise relative to the single EcoRI site (Sutcliffe, 1978).

\section{Localization of ampicillin and sulphonamide resistance determinants of Tn2410}

Recently we described pBP11, a derivative of R1767 coding for resistance to Ap and Su but not $\mathrm{Hg}$, which confers resistance to ampicillin by OXA-2 $\beta$-lactamase (Schmidt et al., 1982). Its genome organization is shown in Fig. 2. The genetic and physical map of pBP11 have been analysed. By cloning the position of its resistance genes has been localized on a $4 \cdot 1 \mathrm{~kb}$ BamHI fragment including restriction sites for $B g l \mathrm{II}, P s t \mathrm{I}, H i n d I I I, H i n d I I$, and $E c o$ RI. Both genes can be separated from each other by the single EcoRI site on this fragment (Schmidt $e t$ al., 1982). On the basis of restriction analysis Tn 2410 carries the same $4.1 \mathrm{~kb}$ BamHI fragment together with a $0.2 \mathrm{~kb} \mathrm{BamHI}$ fragment which is also present on pBP11 close to the single SmaI site on its DNA (Fig. 1). A heteroduplex formed between pBP403 and pBP12, a deletion derivative of pBP11 (Fig. 2), demonstrates a $4.6 \pm 0.2 \mathrm{~kb}$ region of homology next to the single SmaI site on Tn2410 


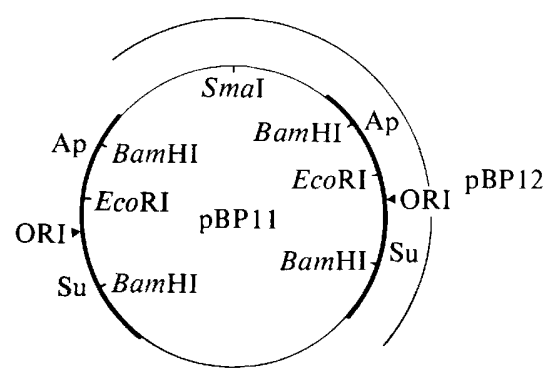

Fig. 2. Schematic representation of the genome organization of pBP11 and its deletion derivative pBP12. The thick lines represent the position of the large inverted repetition of $\mathrm{pBP} 11$ which contains the resistance genes (Ap, Su). EcoRI and BamHI restriction sites are indicated. The DNA segment of pBP11, forming deletion derivative pBP12, is represented by the outer line.

(pBP12 carries no SmaI site at this position) covering the two BamHI fragments in both structures (data not shown). On the basis of these restriction and heteroduplex data the position of the Ap and Su gene could be located in the restriction map of Tn2410 (Fig. 1).

\section{DISCUSSION}

The first report of the identification of a transposable OXA gene was by Yamamoto et al. (1981). That $20 \mathrm{~kb}$ transposon, Tn2603, mediates resistance to ampicillin, streptomycin, sulphonamides, and mercury. The ampicillin resistance is due to the production of an OXA-1 $\beta$ lactamase. In its size and resistance determinants $\mathrm{Tn} 2410$ shows some similarity to $\mathrm{Tn} 2603$, but the ampicillin resistance in Tn 2410 is produced by an OXA- $2 \beta$-lactamase. OXA- 1 and OXA-2 enzymes are distinct in molecular weight ( 24000 for OXA-1 and 46000 for OXA-2), in isoelectric point (7.3 for OXA-1 and 7.45 and 7.7 for OXA-2) and in their ability to hydrolyse methicillin (Dale \& Smith, 1974; Matthew et al., 1979). The OXA-1 enzyme hydrolyses methicillin much more rapidly than benzylpenicillin, whereas the OXA- 2 enzyme hydrolyses methicillin poorly (Dale \& Smith, 1974). The transposon Tn4, formed by insertion of Tn3 into Tn21 (Kopecko et al., 1976) also codes for resistance to ampicillin, sulphonamide and mercury but carries a TEM-1 $\beta$-lactamase gene.

Comparison of the restriction fragments and the resulting map of Tn2603 (Yamamoto et al., 1982) with the data for Tn2410 shows that the ends of both structures seem to be identical. Tn 2410 and Tn 2603 carry at the left end a $4.1 \mathrm{~kb} E c o$ RI fragment and at the right a $1.2 \mathrm{~kb} E c o$ RI fragment contiguous with two small EcoRI fragments containing a small HindIII fragment. Tn21 (Kopecko et al., 1976) also carries at its ends homologous fragments of similar sizes to those of Tn2410 and Tn2603 (unpublished). In Tn21 and Tn2603 the Hg gene is cleaved by the EcoRI site terminating the $4 \cdot 1 \mathrm{~kb} E c o$ RI fragment at the left end on these structures (De La Cruz \& Grinsted, 1982; Yamamoto et al., 1982). By these data we located the $\mathrm{Hg}$ gene on Tn2410 at the same position. The inner part of Tn2410 (7-15 kb, Fig. 1) differs from Tn2603 with respect to the restriction pattern, specifically for EcoRI, HindIII, and BamHI (Yamamoto et al., 1982). We localized the position of the Ap and Su gene on the Tn2410 restriction map by identification of identical Bam HI fragments on Tn2410 and pBP11, a Ap ${ }^{\mathrm{r}}, \mathrm{Su}^{\mathrm{r}}$, but $\mathrm{Hg}^{\mathrm{s}}$ derivative of $\mathrm{R} 1767$. The location of the $\beta$-lactamase genes in Tn2410, Tn2603 and Tn4 is different. Tn 3 inserted at the left end of Tn21 forms Tn4; in Tn2603 the Ap gene is located close to the Sm gene; and in Tn2410 the Ap gene is located beside the Su gene. Despite the different ampicillin genes all three transposons are similar in size and in their physical map, suggesting that these transposons could have been generated from a common ancestor.

Schmidt et al. (1982) have identified an origin of replication in pBP11, located between the Ap and $\mathrm{Su}$ gene (Fig. 2), the region common in both structures, indicating that Tn2410 carries an origin of replication on its DNA. From our present data it is not known whether this origin is expressed together with the origin present on pBR322 in the hybrid plasmid. 
The $4.6 \mathrm{~kb}$ region of homology between $\mathrm{Tn} 2410$ and $\mathrm{pBP} 11$ covering the Ap and Su gene in both structures indicates that $\operatorname{Tn} 2410$ can be fragmented by molecular rearrangements of internal sequences. R1767, carrying Tn2410, was found to rearrange its DNA sequence frequently (Wiedemann, 1981). Derivations of $\mathrm{pBP} 11$ that were $\mathrm{Ap}^{\mathrm{r}}, \mathrm{Su}^{\mathrm{r}}$, but $\mathrm{Hg}^{\mathrm{s}}$ were selected from R1767 after conjugation (Schmidt et al., 1982) and transformation with plasmid DNA (unpublished results), indicating the formation of recombinant plasmids from R1767 at low frequency. The mechanisms involved in these rearrangements are not yet known. McCormick $e t$ al. (1981) reported rearrangements in plasmids carrying Tn3 by deletions stimulated by tnpR between the normal resolution site and similar sites nearby. TnpR- and tnpA-like transposition functions have been identified recently on the Tn 2410 related transposons $\operatorname{Tn} 2603$ and $\operatorname{Tn} 21$ (Tanaka et al., 1982; De La Cruz \& Grinsted, 1982). From these results we speculate, that the tnpR recombination system encoded by $\mathrm{Tn} 2410$ together with the reciprocal recombination system depending on recA functions could stimulate molecular rearrangements of $\mathrm{Tn} 2410$ sequences by the formation of recombinant plasmids carrying Tn2410 and R1767 DNA segments.

\section{REFERENCES}

BachmanN, B. J. (1972). Pedigrees of some mutant strains of Escherichia coli. Bacteriological Reviews 36, 525-527.

Benedick, M., Fennewald, M. \& Shapiro, J. (1977). Transposition of beta-lactamases locus from RP1 into Pseudomonas putida degradative plasmids. Journal of Bacteriology 129, 809-814.

Bennett, P. M., Grinsted, J. \& Richmond, M. H. (1977). Transposition of TnA does not generate deletions. Molecular and General Genetics 154, 205212.

Bolivar, F., Rodriguez, R. L., Greene, P. J., Betlach, M. C., Heynecker, H. L. \& Boyer, H. W. (1977). Construction and characterization of new cloning vehicles. II. A multipurpose cloning system. Gene 2, 95-113.

Coetzee, J. N. (1963). Transduction of swarming Proteus mirabilis. Journal of General Microbiology 33, $1-7$.

Dale, J. W. \& Smith, J. T. (1974). R-factor mediated beta-lactamases that hydrolyse oxacillin: evidence for two distinct groups. Journal of Bacteriology 119 , 351-356.

Davis, R. W., Simon, M. \& Davidson, N. (1971). Electron microscope heteroduplex methods for mapping regions of base sequence homology in nucleic acids. Methods in Enzymology 21, 413-428.

De la Cruz, F. \& Grinsted, J. (1982). Genetic and molecular characterization of $\mathrm{Tn} 21$, a multiple resistance transposon from R100.1. Journal of Bacteriology 151, 222-228.

Demerec, M., Adelberg, E. A., Clark, A. J. \& HartmanN, F. E. (1966). A proposal for an uniform nomenclature in bacterial genetics. Genetics $\mathbf{5 4}, 61$ 76.

HEDGES, R. W. \& JACOB, H. E. (1974). Transposition of ampicillin resistance from RP4 to other replicons. Molecular and General Genetics 132, 31-40.

Hedges, R. W., Datta, N., Kontomichalou, P. \& SMITH, J. R. (1974). Molecular specificities of Rfactor-determined beta-lactamases: correlation with plasmid compatibility. Journal of Bacteriology 117 , $56-62$.

Hefrron, F., Sublett, R., Hedges, R. W., Jacob, A.
\& Falkow, S. (1975). Origin of the TEM betalactamase gene found on . plasmids. Journal of Bacteriology 122, 250-256.

Klein, R. D., Selsing, E. \& Wells, R. D. (1980). A rapid microscale technique for isolation and recombinant plasmid DNA suitable for restriction enzyme analysis. Plasmid 3, 88-91.

KOPECKO, D. J. (1980). Specialized genetic recombination systems in bacteria: their involvement in gene expression and evolution. Progress in Molecular Subcellular Biology 7, 135-234.

Kopecko, D. J. \& SoHen, S. N. (1975). Site-specific recA independent recombination between bacterial plasmids: involvement of palindromes at the recombinational loci. Proceedings of the National Academy of Sciences of the United States of America 72, 13731377.

Kopecko, D. J., Brevet, J. \& Cohen, S. N. (1976). Involvement of multiple translocating DNA sequence and recombinational hotspots in the structural evolution of bacterial plasmids. Journal of Molecular Biology 108, 333-360.

KupersZoCK-PorTNoy, Y. M., LOVETT, M. A. \& HeLINSKI, D. R. (1974). Strand and site specificity of the relaxation event for the relaxation complex of the antibiotic resistance plasmid R6K. Biochemistry 13, 5484-5490.

KUSHNER, S. R. (1978). An improved method for transformation of Escherichia coli with ColEl derived plasmids. In Proceedings of the International Symposium of Genetic Engineering. Amsterdam: Elsevier.

LENNOX, E. S. (1955). Transduction of linked genetic characters of host by bacteriophage P1. Virology 1 , 190-206.

Matthew, M., Harris, A. M., Marshall, M. J. \& Ross, G. W. (1975). The use of analytical isoelectric focusing for determination and identification of $\beta$-lactamases. Journal of General Microbiology 88 , 169-178.

MatThew, M. \& Harris, A. M. (1976). Identification of $\beta$-lactamases by analytical isoelectric focusing: Correlation with bacterial taxonomy. Journal of General Microbiology 94, 55-67. 
MatTHEw, M. (1979). Plasmid-mediated $\beta$-lactamases of gram-negative bacteria: properties and distribution. Journal of Antimicrobial Chemotherapy 5, 349358.

Matthew, M., Hedges, R. W. \& Smith, J. T. (1979). Types of beta-lactamase determined by plasmids of gram-negative bacteria. Journal of Bacteriology 138, 657-662.

McCormick, M., Wishart, W., Ohtsubo, H., HefFRON, F. \& OHTSUBO, E. (1981). Plasmid cointegrates and their resolution mediated by transposon $\mathrm{Tn} 3$ mutants. Gene 15, 103-118.

Novick, R. P., Clowes, R. C., Cohen, S. N., Curtiss III, R., DatTa, N. \& Falkow, S. (1976). Uniform nomenclature for bacterial plasmids: a proposal. Bacteriological Reviews 40, 168-189.

OHTSUBo, H., OHMORI, H. \& OHTSUBO, E. (1979). Nucleotide sequence analysis of the ampicillin resistance transposon Tn3: implications for insertion and deletion. Cold Spring Harbor Symposia on Quantitative Biology 43, 1269-1277.

Sanger, F., AIr, G. M., Barell, B. C., Brown, N. L., Coulson, A. R., Fiddes, J. C., Hutchinson III, C. A., Slocombe, P. M. \& Smith, M. (1977). Nucleotide sequence of bacteriophage $\phi \times 174$ DNA. Nature, London 265, 687-695.

Schmidt, F., van Treeck, U. \& WiedemanN, B. (1982). Multimerization and replication of plasmid pBP11. Plasmid 8, 126-140.

Simpson, I. N., HaRPer, P. B. \& O'Callaghan, C. H. (1980). Principle of $\beta$-lactamases responsible for resistance to $\beta$-lactam antibiotics in urinary tract infections. Antimicrobial Agents and Chemotherapy 17, 929-936.

SutClifFe, J. G. (1978). pBR322 restriction map derived from the DNA sequence: accurate DNA size markers up to 4361 nucleotide pairs long. Nucleic Acids Research 5, 2721-2728.

Sykes, R. B. \& MATTHEW, M. (1976). The $\beta$-lactamases of gram-negative bacteria and their role in resistance to $\beta$-lactam antibiotics. Journal of Antimicrobial Chemotherapy 2, 115-157.

Tanaka, M., Harafuji, H. \& Yamamoto, T. (1982). A gene and its product required for transposition of resistance Tn2603. Journal of Bacteriology 151, 723728.

Yamada, Y., Calame, K. L., Grindley, J. N. \& NAKADA, D. (1979). Location of ampicillin resistance transposon, Tn1701, in a group of small, nontransferring plasmids. Journal of Bacteriology 137, 990-999.

Yamamoto, T., Tanaka, M., Nohara, C., Fukanada, Y. \& YAMAGISHI, S. (1981). Transposition of the oxacillin-hydrolyzing penicillinase gene. Journal of Bacteriology 145, 808-813.

Yamamoto, T., TaNAKa, N., Baba, R. \& Yamagishi, S. (1982). Physical and functional mapping of $\operatorname{Tn} 2603$, a transposon encoding ampicillin, streptomycin, sulfonamide, and mercury resistance. Molecular and General Genetics 181, 464-469.

WiedemanN, B. (1981). Development of bacterial resistance to antibiotics. In New Trends in Antibiotics: Research and Therapy, pp. 179-202. Edited by G. Gialdroni Grassi \& L. D. Sabath. Amsterdam: Elsevier.

Wood, W. B. (1966). Host specificity of DNA produced by Escherichia coli: bacterial mutations affecting the restriction and modification of DNA. Journal of Molecular Biology 169, 118-133. 